C 2021 by the author. This work is licensed under

Creative Commons Attribution 4.0 International License

https://creativecommons.org/licenses/by/4.0/

\title{
UPDATES ON INFORMATION REGARDING THE DIRECTORY OF OPEN ACCESS JOURNALS PLATFORM MAY INCREASE ITS RELIABILITY
}

\author{
Received: September 6, 2021 \\ Accepted: September 26, 2021
}

\section{Jaime A. Teixeira da Silva ${ }^{{ }^{*}}$}

${ }^{1}$ Independent researcher, P. O. Box 7, Ikenobe 3011-2, Kagawa-ken 761-0799, Japan

* Corresponding author: Jaime A. Teixeira da Silva, PhD, Independent researcher, P. O. Box 7, Ikenobe 30112, Kagawa-ken 761-0799, Japan

E-mail: jaimetex@yahoo.com

\begin{abstract}
The Directory of Open Access Journals (DOAJ) is a leading whitelist of open access journals (OAJs), that is, OAJs that are presumably safe to publish in, or scholarly, because they follow best practices established by COPE/DOAJ/OASPA/WAME. Academics rely on the DOAJ to select OAJs of choice, and filter for particular needs, for example, English-only or no article processing charges. A search of DOAJ-indexed OAJs publishing work on ornamental research identified five OAJs, but $60 \%$ of them had incorrect and thus misleading information. The 'last update' of all five OAJs were outdated. The DOAJ must ensure that indexed OAJs have updated information. The Editors of OAJs also bear responsibility.
\end{abstract}

Keywords: Academic societies, Bibliographies as topic, COPE/DOAJ/OASPA/WAME Best principles, Open access publishing, Periodicals as topic, Predatory journals, Ethics, Whitelists

How to cite: Teixeira da Silva JA. Updates on information regarding the Directory of Open Access Journals platform may increase its reliability. Cent Asian $J$ Med Hypotheses Ethics 2021:2(3):162-165. https://doi.org/10.47316/caimhe.2021.2.3.05

\section{INTRODUCTION}

The Directory of Open Access Journals (DOAJ) has become one of the leading contenders for safe-topublish-in open access journals (OAJs) in recent years. The DOAJ itself claims that it "is a community-curated online directory that indexes and provides access to high-quality, open access (OA), peer-reviewed journals" [1]. The DOAJ Seal is the DOAJ's maximum stamp of academic quality and scholarly approval [2]. To date, the DOAJ has claimed to index 16,875 OAJs, 11,972 of which do not carry any article processing charges (APCs). Several of the DOAJ-indexed OAJs had (7 years ago) [3], and continue to have, variable pricing options related to APCs. In terms of functionality, the database of OAJs is well structured and organized, and the search function is useful and user-friendly. Each entry offers basic information about the publisher, best practices, journal metadata, copyright or publishing rights/licenses, and archival, and links to relevant OAJ websites. If correct, accurate and up-to-date, such information is useful for academics searching for a potential target OAJ to submit their research findings or paper.

However, the DOAJ was not always this well-structured, and has faced challenges and criticisms in the past. The biggest challenge that the DOAJ likely faced in its history was the apparent listing of unscholarly (possibly "predatory") OAJs. Facing public scrutiny and pressure from scholarly OAJs, publishers and societies, the DOAJ reassessed its indexed members in a thorough process of reaccreditation [4]. The DOAJ is considered by OA scholars to be a premium OAJ whitelist, particularly 
those journals that carry the DOAJ Seal, which is the DOAJ's mark of scholarly quality [5], alongside its ethics branding, namely that those OAJs follow principles of transparency and best publishing practices [6]. It is not necessary for all DOAJ-indexed OAJs to be Plan Scompliant [7].

Despite these guarantees of quality, fluxes in OAJs that were indexed and then delisted from the DOAJ suggests that the screening criteria are still not as robust as they should be and that the DOAJ is lacking careful review of its indexed OAJs [8]. In January 2021, less than one-third of DOAJ-indexed OAJs had a 'last update' date in 2020, indicating that $70 \%$ of the OAJs had information outdated by at least one year [9]. This affects the reliability of information provided by the DOAJ to academics, and may thus reduce the usefulness and reliability of the DOAJ platform [10].

\section{TESTING THE DOAJ: APPLICATION TO ORNAMENTAL RESEARCH}

To test the reliability of the DOAJ in identifying OAJs that publish ornamental research, which is a highly specialized field of horticulture and a subset of plant science, the DOAJ was searched using the keyword "ornamental". Surprisingly, without setting any filters, only five hits were revealed. In fact, the objective was to find OAJs that published papers in English and that did not charge an APC, given that the author is unfunded and thus unable to pay APCs, or OAJs with an APC waiver. The five possible target journals (in order of listing) were as follows: Journal of Horticulture and Postharvest Research (JHPR), Romanian Journal of Horticulture, Ornamental Horticulture (OH), Revista Chapingo Serie Horticultura (RCSH), and Horticultural Science (HS). This is a small percentage of all OAJs indexed by the DOAJ. Adjusting the search function to the broader keyword "horticulture" revealed 55 choices of OAJs. However, to appreciate if they publish work on ornamental research, each had to be screened manually, totally defeating the purpose of a search at the DOAJ for "ornamental".

All five entries are outdated, that is, the 'last update' ranges from November 8, 2017 to February 24, 2021. One $\mathrm{OAJ}(\mathrm{OH})$ published in Brazil is indicated as having no APC [11], even though the journal website indicates that the APC is 300 Brazilian Reais (about €48) [12]. Another OAJ (JHPR) published in the IR Iran is indicated as having an APC of one million Iranian Rials (about €20) [13], although the journal website indicates that the APC is waived for non-Iranian authors [14]. For a third OAJ (HS) published in the Czech Republic, the APC is indicated as being $€ 320$ [15]. However, it is in fact $€ 320$ plus VAT, which in the Czech Republic is $15 \%$ for books/journals, so the actual price of the APC would be $€ 368$ [16] (or €48 higher than the indicated DOAJ price). The DOAJ thus lists incorrect and misleading information for at least $60 \%$ of the five screened OAJs. Consequently, from among these five possible target OAJs, only two of relevance and fitting the desired criteria (English, no APCs) actually fitted the desired profile, although each had to be independently and manually verified since the DOAJ information was not always accurate.

Separately, one of the OAJs (RCSH) [17] indicates a mandatory ORCID for all authors, which is a very important exclusionary policy that can be perceived as being unfair or even discriminatory against those without an ORCID and who might not wish to obtain one [18]. Therefore, for this OAJ [19], and for all others indexed by the DOAJ, it would be useful to list ORCID requirements for submission in the 'best practices' section of each OAJ's profile to match the journal website's instructions for authors.

\section{CONCLUDING REMARKS}

OAJs and publishers indexed by the DOAJ, a publishing whitelist, are only included based on best publishing practices. In exceptional cases, a "superior" academic quality stamp called the DOAJ Seal exists in approximately $10 \%$ of all DOAJ-indexed OAJs [2]. In this paper, a search for OAJs related to ornamental research only revealed five results, all of which had outdated information and at least two of which had erroneous and thus misleading and unreliable information. This status affects the usefulness of that information, and negatively impacts the academic experience of would-be authors seeking a possible target OAJ to publish their work. Admittedly, the sample size is only five and similar analyses would need to be conducted by other authors in other fields of study, to appreciate whether the findings made by the Morrison working group $[9,10]$ holds true for other OAJs indexed by the DOAJ.

Currently, the DOAJ appears to be very flexible and not at all strict with respect to the updated information status of indexed OAJs. That is a problem. It relies on the owners of OAJs and OA publishers to provide updates. This policy should change, and the DOAJ should "chase" indexed OAJs and OA publishers to provide at minimum yearly updates, or better, updates every six months. Those OAJs and OA publishers should have the responsibility of ensuring that all information on their DOAJ profile is correct, accurate and up-to-date. To 
inculcate a culture of academic responsibility and to appreciate the importance of such indexing for their publishing portfolio and reputation in the world of $O A$ publishing, a soccer-like penalty system could be implemented. In such a system, any DOAJ-indexed OAJ and $O A$ publisher that is indexed but fails to update after six months following an automated DOAJ-issued reminder (yellow card), and then again after one year following an additional request and reminder, should be delisted (red card). Strict re-enlisting policies should also be in place to avoid frivolous use or abuse of the DOAJ's indexing protocol.

Finally, neither the "quality" of OAJs indexed by the DOAJ, nor the integrity of the covered literature have been tested. This is an essential post-publication analysis that eventually needs to be conducted for all DOAJ-indexed OAJs.

\section{CONFLICTS OF INTEREST}

None declared

\section{REFERENCES}

1. DOAJ. About the directory. Available from: https://doaj.org/ [Accessed September 22, 2021].

2. DOAJ. The DOAJ Seal. Available from: https://doaj.org/apply/seal/ [Accessed September 22, 2021].

3. Morrison H, Salhab J, Calvé-Genest A, Horava T. Open access article processing charges: DOAJ survey May 2014. Publications 2015;3(1):1-16.

4. Frantsvåg JE. The DOAJ spring cleaning 2016 and what was removed - tragic loss or good riddance? Publications 2019;7(3):45.

5. Rodrigues RS, Abadal E, de Araújo BKH. Open access publishers: The new players. PLoS ONE 2020;15(6):e0233432.

6. COPE/DOAJ/OASPA/WAME. Principles of transparency and best practice for scholarly publications. Guidelines (version 3, 12 January 2019). Available from: https://doi.org/10.24318/cope.2019.1.12 [Accessed September 22, 2021].

7. DOAJ. cOAlition S releases the Journal Checker Tool, a search engine that checks Plan S compliance. Available from: $\quad$ https://blog.doaj.org/2020/11/18/coalition-s-releases-the-journal-checker-tool-a-search-engine-thatchecks-plan-s-compliancel [Accessed September 22, 2021].

8. Teixeira da Silva JA, Dobránszki J, Al-Khatib A, Tsigaris P. Challenges facing the DOAJ (Directory of Open Access Journals) as a reliable source of open access publishing venues. J Educ Media Libr Sci 2018;55(3):349358.

9. Zhao X, Borges L, Morrison H. Some limitations of DOAJ metadata for research purposes. Sustaining the Knowledge Commons. Available from: https://sustainingknowledgecommons.org/2021/02/10/some-limitationsof-doaj-metadata-for-research-purposes/ [Accessed September 22, 2021].

10. Zhao X, Borges L, Morrison H. Improving the DOAJ metadata - Why and how. Available from: https://sustainingknowledgecommons.org/2021/04/06/improving-the-doaj-metadata-why-and-how/ [Accessed September 22, 2021].

11. DOAJ. Ornamental Horticulture. Available from: https://doaj.org/toc/2447-536X [Accessed August 30, 2021].

12. Ornamental Horticulture. Available from: https://ornamentalhorticulture.emnuvens.com.br/rbho. [Accessed August 30, 2021].

13. DOAJ. Journal of Horticulture and Postharvest Research. Available from: https://doaj.org/toc/2588-6169 [Accessed August 30, 2021].

14. Journal of Horticulture and Postharvest Research. Available from: https://ihpr.birjand.ac.ir/ [Accessed August 30, 2021].

15. DOAJ. Horticultural Science. Available from: https://doaj.org/toc/1805-9333. [Accessed August 30, 2021].

16. Horticultural Science. Instructions for authors. Available from: https://www.agriculturejournals.cz/web/hortsci/wpcontent/uploads/sites/6/HORTSCI_authorInstruction.pdf [Accessed August 30, 2021].

17. Revista Chapingo Serie Horticultura Guide for authors. Available from: https://revistas.chapingo.mx/horticultura/?section=author\&subsec=guide [Accessed August 30, 2021].

18. Teixeira da Silva JA. ORCID: Issues and concerns about its use for academic purposes and research integrity. Ann Libr Inf Stud 2020;67(4):246-250.

19. DOAJ. Revista Chapingo Serie Horticultura. Available from: https://doaj.org/toc/2007-4034. [Accessed August 30, 2021]. 


\section{DIRECTORY OF OPEN ACCESS JOURNALS ПЛАТФОРМАСЫНДАҒЫ АҚПАРАТТЫҢ ЖАңАРТЫЛУЫ ОНЫҢ НАҚТЫЛЫҒЫН АРТТЫРУЫ МҮМКІН}

\section{Түйіндеме}

Directory of Open Access Journals (DOAJ) - бұл ғылыми жұмыстарды жариялауға болатын ашық қол жетімді журналдардың ең беделді тізімі, өйткені олар жаһандық редакторлық ұйымдар белгілеген ұстанымдарға сәйкес келеді. Ғалымдар мақсатты журналдарды таңдау үшін DOAJ қолданады. Ыңғайлы болу үшін платформада параметрлер бойынша сүзгі қарастырылған, мысалы, мақалаларға ақы төлеуді талап етпейтін ағылшын тіліндегі журналдар мен басылымдарды таңдау үшін. Декорация саласындағы зерттеулер үшін ашық қол жетімді журналдарды іздеу платформада ескірген, дұрыс емес және жаңылыстыратын ақпараты бар бес басылымды анықтады. Индекстелген көздер жаңартылған ақпаратымен келтірілгеніне DOAJ кепілдік беруі керек. Бұл дереккөздердің редакторлары да жауапты болып табылуы тиіс.

Түйінді сөздер: Академиялық қоғамдар, библиография тақырып ретінде, COPY / DOAJ / OASPA / WAME ең жақсы ұстанымдары, ашық қол жетімді басылымдар, мерзімді басылымдар тақырып ретінде, жыртқыш журналдар, этика, ақ тізімдер

Дәйексөз үшін: Тейшейра да Силва Ж.А. Directory of Open Access Journals платформасындағы ақпараттың жаңартылуы оның нақтылығын арттыруы мүмкін Ашық қолжетімді журналдар анықтамасын жаңартылуы ашық қолжетімділік платформасының сенімділігін арттыратын мүмкіндік туралы. Медициналық гипотеза мен этиканың Орта Азиялық журналы. 2021:2(3):162-165. https://doi.org/10.47316/cajmhe.2021.2.3.05

\section{ОБНОВЛЕНИЕ ИНФОРМАЦИИ НА ПЛАТФОРМЕ DIRЕСТОRY OF OPEN ACCESS JOURNALS МОЖЕТ ПОВЫСИТЬ ЕЁ ДОСТОВЕРНОСТЬ}

\section{Резюме}

Directory of Open Access Journals (DOAJ) - это наиболее авторитетный регистр журналов открытого доступа, в которых можно публиковать научные работы, поскольку они привержены принципам, установленным глобальными редакторскими организациями. Ученые используют DOAJ для отбора целевых журналов. Для удобства на платформе предусмотрен фильтр по параметрам, например, для выбора англоязычных журналов и изданий, не требующих оплату за статьи. Поиск журналов открытого доступа для исследований в области декорации выявил пять изданий, по поводу которых на платформе содержалась устаревшая, неверная и вводящая в заблуждение информация. DOAJ должен гарантировать, что проиндексированные источники представлены с обновленной информацией. Редакторы этих источников также должны нести ответственность.

Ключевые слова: Академические общества, библиографии как тема, лучшие принципы СОРЕ / DOAJ / OASPA / WAME, публикации открытого доступа, периодические издания как тема, хищнические журналы, этика, белые списки

Для цитирования: Тейшейра да Силва Ж.А. Обновление информации на платформе Directory of Open Access Journals может повысить её достоверность. Центральноазиатский журнал медицинских гипотез и этики. 2021:2(3):162-165. https://doi.org/10.47316/cajmhe.2021.2.3.05 